\title{
Identification of leptospiral 3-hydroxyacyl-CoA dehydrogenase released in the urine of infected hamsters
}

\author{
Takaya Segawa ${ }^{1 *}$, Kazuko H Nomura ${ }^{2}$, Sharon Yvette Angelina M Villanueva ${ }^{1}$, Mitsumasa Saito ${ }^{1}, K^{2}$ azuya Nomura ${ }^{2}$, \\ Nina G Gloriani ${ }^{3}$ and Shin-ichi Yoshida ${ }^{1}$
}

\begin{abstract}
Background: Leptospirosis is a global zoonosis caused by pathogenic Leptospira. The non-specific clinical signs and symptoms of leptospirosis lead to its misdiagnosis. To date, there is still no reliable rapid test kit that can accurately diagnose leptospirosis at bedside or in field. In this research, with the ultimate goal of formulating a rapid and accurate diagnostic tool for leptospirosis, we aimed to identify leptospiral proteins excreted in urine of infected hamsters, which are thought to mimic Weil's disease.
\end{abstract}

Results: Hamsters were subcutaneously infected with leptospires, and the general attributes of urine as well as the proteins excreted in it were examined. Some leptospiral proteins were found to be excreted in the urine from the early phase of infection. The most important finding of this study was the detection of the lipid-metabolizing enzyme, 3-hydroxyacyl-CoA dehydrogenase (HADH), before the onset of illness, when leptospires were not yet detected in the urine of infected hamsters.

Conclusions: This is the first report on the detection of leptospiral HADH in the host urine, which may be a possible candidate leptospiral antigen that can be used in the early diagnosis of human and animal leptospirosis.

Keywords: Leptospirosis, 3-hydroxyacyl-CoA dehydrogenase, Urine, Hamster, Diagnosis

\section{Background}

Leptospirosis is a global zoonosis caused by the pathogenic Leptospira spp. Outbreaks of leptospirosis usually occur after heavy rains followed by floods in tropical and subtropical developing countries, and recreational activities in developed countries [1,2]. The genus Leptospira is comprised of 21 species and more than 300 serovars. Animals may become maintenance hosts of some serovars or incidental hosts of others [3]. Infection of accidental hosts may cause severe or fatal disease. Wild rats, dogs, buffaloes, horses, and pigs are known to contract the disease and the surviving animals maintain the organisms in their kidneys. Infected animal urine contains leptospires, which may contaminate the environment once excreted, becoming a new source of infection for humans and susceptible

\footnotetext{
* Correspondence: tsegawa@bact.med.kyushu-u.ac.jp

'Department of Bacteriology, Graduate School of Medical Sciences, Kyushu University, Fukuoka 812-8582, Japan

Full list of author information is available at the end of the article
}

animals. Infection of humans or animals occurs when leptospires penetrate both normal and injured skin and mucosal surfaces after direct contact with the urine of infected animals or indirectly from contaminated environments $[1,4]$.

Signs and symptoms of human leptospirosis are usually mild, however, $5 \%$ of cases develop the severe form presenting jaundice, renal failure, and pulmonary hemorrhage [1,2,4-6]. This zoonotic infection is treatable but its early phase has clinical presentations similar to many other diseases thereby complicating its clinical diagnosis. Early diagnosis of leptospirosis is essential to prevent progression to the severe stage because antibiotic treatment is effective when it is initiated early in the course of the disease.

The gold standards for diagnosis of leptospirosis are isolation of Leptospira by culture from blood, urine or tissues of infected hosts and the microscopic agglutination test (MAT) to detect antibody. However, results of these diagnostic methods can only be evaluated more than 
10 days after the onset of illness. Furthermore, technical expertise is needed in order to perform the culture and MAT. In attempts to replace these two methods, other diagnostic methods were developed such as enzyme-linked immunosorbent assay (ELISA) [7], polymerase chain reaction (PCR) [8-11], and so on [12-16]. However, these are not simple or rapid tests that can be used at bedside $[1,2,4,17]$ and sophisticated equipment is needed in order to perform PCR. In addition, with the exception of PCR, the sensitivities of the other assays are not satisfactory, especially during the acute phase of infection [18]. At present there is a lack of available kits that are able to detect leptospiral antigens in patient samples such as urine. Furthermore, there is also a need for simple and rapid leptospirosis diagnostic kits that are cheap, highly sensitive, highly specific, and can easily be used at bedside or in the field.

Urine is expected to be the best sample for diagnosis, because the urine of leptospirosis patients contains leptospiral antigens and can be collected easily [19-26]. Urine of patients has often been used for culture of Leptospira, however, more information on proteins can be obtained from urine [27].

The golden Syrian hamster is susceptible to Leptospira infection, and acute leptospirosis in the hamster model reproduces the severe form of human leptospirosis, and is therefore useful in evaluating diagnostic methods [28]. In this study, we analyzed the characteristics and protein components of Leptospira-infected hamster urine in order to identify proteins that may be possibly used in developing rapid and accurate leptospiral antigen diagnostic kits. We identified a leptospiral protein, 3hydroxyacyl-CoA dehydrogenase $(\mathrm{HADH})$, which was found to be excreted in the urine of hamsters during the early phase of infection.

\section{Results}

\section{Changes in urine characteristics of hamsters during} Leptospira infection

Hamsters were subcutaneously infected with $10^{3}$ leptospires (strain K64), and their urine was collected daily in metabolic chambers for $6 \mathrm{~h}$. All infected hamsters became markedly sick after the seventh day showing decreased mobility and body weight, ruffled fur, and decreased food and water intake, and became moribund from the eighth day post infection (Figure 1A). We confirmed that the cause of death was leptospirosis because leptospires were isolated from the blood, urine, and organs (lungs, livers, kidneys, spleens, and brains) of moribund hamsters. Normal hamster urine was alkaline (Figure 1B) and milky (Figure 1C). However, it became acidic (Figure 1B) and clear (Figure 1C) after the seventh day of infection. Urine culture was negative for leptospires until the sixth day, but became positive from the seventh day post infection (Figure 1A). Using urinalysis strips, we also found that the

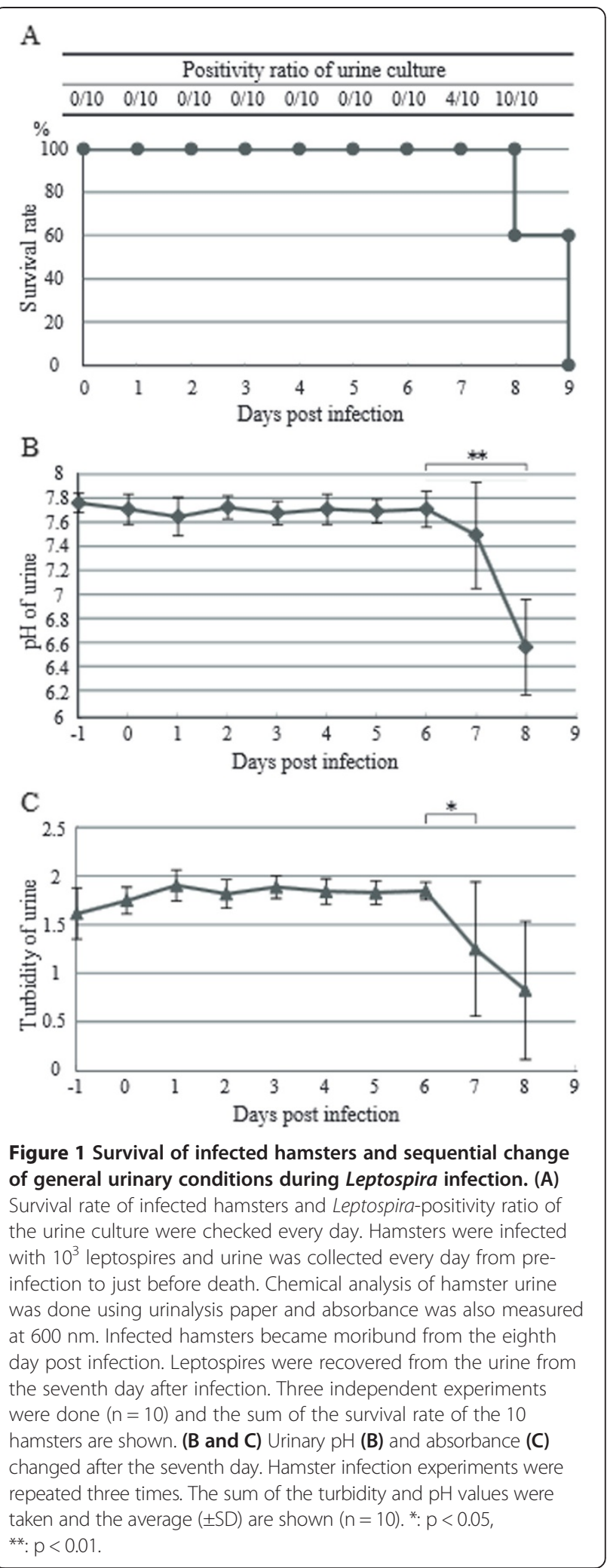

levels of glucose, specific gravity, blood, protein and bilirubin increased at the same time, whereas the levels of urobilinogen, nitrite, leukocyte and ketone did not change. 
Urinary protein level was $30 \mathrm{mg} / \mathrm{dl}$ before infection, and increased to $300 \mathrm{mg} / \mathrm{dl}$ on the seventh day post infection.

\section{Changes in hamster urinary proteins during leptospiral infection}

The hamster urine was collected daily from pre-infection to just before death and the protein compositions were compared using SDS-PAGE. Until the sixth day post infection, urinary protein compositions were almost the same as that of pre-infection. Significant change was observed after 7 days of infection, particularly an increase in the density of approximately $66 \mathrm{kDa}$ protein which is thought to be albumin (Figure 2A).

For detecting leptospiral proteins in hamster urine, we performed immunoblotting with rabbit polyclonal antibody against $L$. interrogans serovar Manilae. Three bands with sizes of 65,52 , and $30 \mathrm{kDa}$ were detected in the postinfection urine (Figure 2B). These bands were already detected during the early phase of post-infection. During this phase, the hamster appeared healthy and no viable leptospires were recovered from the urine. $26 \mathrm{kDa}$ protein was detected in urine before and during infection so this protein was not a result of infection.

\section{Comparative analysis of urinary protein composition before and after Leptospira infection by using two} dimensional electrophoresis (2-DE) and immunoblotting As shown in the results of SDS-PAGE (Figure 2A), the composition of urinary proteins was found to have changed drastically after the seventh day of infection.
To compare these components in detail, the urinary proteins of pre-infection and seventh day of infection were analyzed by 2-DE (Figure 3). The 2-DE pattern of urinary proteins changed after Leptospira infection. It was found that the level of approximately $66 \mathrm{kDa}$ protein in the urine significantly increased on the seventh day (Figure 3A and B). By immunoblotting using anti- $L$. interrogans $\mathrm{pAb}$, the $60 \mathrm{kDa}$ spots were detected (Figure $3 \mathrm{D}$, arrow). However, spots with other sizes were not detected in hamster urine (Figure 3D). 2-DE analysis were also done for urine samples at 3-4 days infection however the protein pattern was found to be the same as pre-infection urine samples and further analysis by immunoblot was also unable to detect any protein spots (data not shown).

\section{Proteins with increased levels after Leptospira infection}

A total of 29 protein spots that had increased density after infection (Figure 3B) were selected and analyzed by LC/ MS/MS analysis. Database analysis showed that these urinary proteins were albumin, alpha-1-antitrypsin, alpha1-inhibitor III, angiotensinogen, apolipoprotein A-I, ceruloplasmin, haptoglobin, pancreatic trypsin 1, pregnancy protein $60 \mathrm{kDa}$, protease serine 1, transferrin, transthyretin, AMBP protein, vitamin D-binding protein and $\mathrm{Cu} / \mathrm{Zn}$ superoxide dismutase (Table 1). Most of these proteins were serum proteins, which are usually detected in the urine of patients with renal failure. It is noteworthy that some of the leptospiral proteins were also identified as ABC transporter, 3-hydroxyacyl-CoA dehydrogenase



Figure 2 SDS-PAGE and immunoblotting of hamster urine protein during Leptospira infection. (A) Compositions of hamster urinary proteins were compared according to infection periods. Hamster urine was collected and prepared for SDS-PAGE. The urine of three hamsters was mixed for each infection period. The protein content of each sample was $5 \mu \mathrm{g}$. After separation with SDS-PAGE, the gel was stained by silver staining. (B) The anti-L. interrogans pAb recognized leptospiral proteins in infected-hamster urine by immunoblotting. These experiments were repeated three times, and the representative data are shown in this figure. 

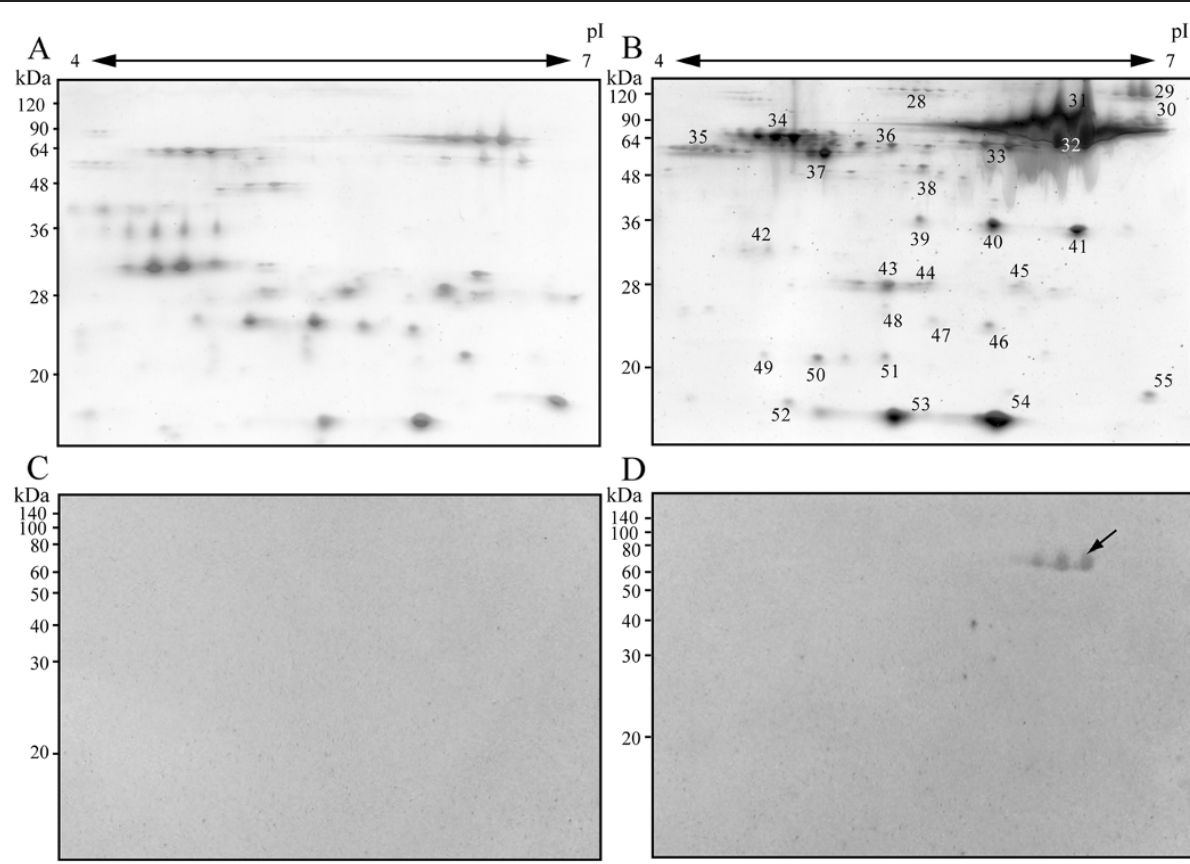

$\mathrm{D}$

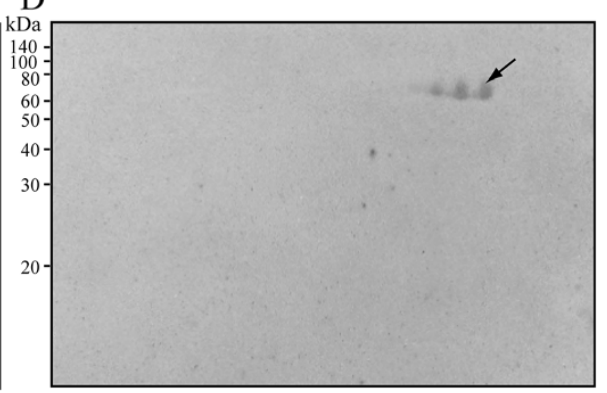

Figure 3 2-DE analysis of normal and infected hamsters urine. Urinary protein patterns of hamsters were compared by 2-DE analysis; (A, C) before infection; (B, D) 7-8 days post-infection. The urine of three hamsters was mixed for each infection period. The total protein content of each sample was $20 \mu \mathrm{g}$. Each pattern of urinary protein was separated by pl (4-7), 12.5\% acrylamide gel, and subsequently silver staining (A, B), or immunoblotting with anti-L. interrogans pAb was done (C, D). Arrows (D) show spots of $60 \mathrm{kDa}$ that reacted with the polyclonal antibody at 7-8 days post-infection.

Each experiment was repeated three times, and the representative data are shown in this figure.

Table 1 List of hamster proteins excreted in urine that had increased levels of expression during infection

\begin{tabular}{|c|c|c|c|c|c|}
\hline Spot no. & Accession no.† & Protein annotation & $\mathrm{MW}(\mathrm{kDa})$ & pl & Urinary marker of diseases (Reference) \\
\hline 28 & gi:110347564 & ceruloplasmin isoform b [Mus musculus] & 121872 & 5.53 & Acute renal transplant rejection $[29,30]$ \\
\hline 29 & gi:83816939 & alpha-1-inhibitor III [Rattus norvegicus] & 165038 & 5.7 & No reports \\
\hline $30,32,33,38$ & gi:58585560 & albumin [Microtus fortis fortis] & 70261 & 5.91 & $\begin{array}{l}\text { Glomerular disease [31,32], } \\
\text { Diabetes mellitus type } 2 \text { [33] }\end{array}$ \\
\hline 31 & gi:17046471 & transferrin [Mus musculus] & 78794 & 6.92 & Glomerular disease $[31,32]$ \\
\hline 34 & gi:68052028 & Alpha-1-antitrypsin precursor & 46019 & 5.55 & Glomerular disease [32] \\
\hline 35 & gi:191388 & pregnancy protein $60 \mathrm{kDa}$ & 47574 & 8.53 & No reports \\
\hline 36 & gi:19705570 & angiotensinogen [Rattus norvegicus] & 52177 & 5.37 & Chronic kidney disease [34] \\
\hline 37 & gi:193446 & vitamin D-binding protein [Mus musculus] & 54647 & 5.26 & Glomerular disease $[31,32]$ \\
\hline $39-41$ & gi:41019123 & Haptoglobin precursor & 39090 & 5.76 & $\begin{array}{l}\text { Glomerular disease }[31,32], \\
\text { Diabetes mellitus type } 2 \text { [33] }\end{array}$ \\
\hline 42 & gi:2497695 & AMBP protein precursor & 39669 & 5.87 & Diabetes mellitus type $2[33,35]$ \\
\hline $43-45,48$ & gi:62899898 & Apolipoprotein A-I precursor & 30720 & 5.86 & Glomerular disease [36] \\
\hline $46,51,52$ & gi:6981420 & pancreatic trypsin 1 [Rattus norvegicus] & 26627 & 4.71 & Pancreatitis [31] \\
\hline 47,49 & gi:16716569 & protease, serine, 1 [Mus musculus] & 26802 & 4.75 & No reports \\
\hline $50,53,54$ & gi:6981684 & transthyretin [Rattus norvegicus] & 15852 & 5.77 & $\begin{array}{l}\text { Glomerular disease }[31,32] \\
\text { Diabetes mellitus type } 2[33]\end{array}$ \\
\hline 55 & gi:226471 & Cu/Zn superoxide dismutase & 15923 & 6.03 & Endemic nephropathy [37] \\
\hline
\end{tabular}

${ }^{\dagger}$ http://www.ncbi.nlm.nih.gov/protein/. 
(HADH), chloride channel, and conserved hypothetical proteins in the urine (Table 2).

\section{Identification of HADH in hamster urine}

As mentioned in the previous section, candidate leptospiral proteins in urine were selected based on the results of LC/MS/MS analysis. In order to identify leptospiral proteins that are excreted in hamster urine during infection, recombinant proteins for each selected protein were made. The proteins were screened by immunoblotting with anti-L. interrogans pAb. Among them, only $\mathrm{HADH}$ reacted to the antibody. The amino acid sequence of HADH are shown in the Additional file 1: Table S1 and had a coverage of $27 \%$. The $\mathrm{rHADH}$ was purified with TALON $^{\bullet}$ Metal Affinity Resin (Clontech) and its expression was confirmed with coomassie brilliant blue (CBB) staining (Figure 4A) and immunoblotting by anti-His (Cterm) antibody (Figure 4B). The anti-L. interrogans pAb also recognized the $\mathrm{rHADH}$ (Figure $4 \mathrm{C}$ ).

\section{Detection of HADH in infected hamster urine with antiserum}

We produced anti-rHADH antiserum in rabbits, and examined its reactivity to $\mathrm{rHADH}$ by immunoblotting. The rabbit antiserum recognized the recombinant protein (data not shown). We then performed immunoblotting of urine samples as in Figure $2 \mathrm{~B}$ and the antiserum reacted with the post-infection samples (Figure 5A). The reacted protein increased after the seventh day of infection (Figure 5B). The protein was found to be excreted in the urine before leptospires were shed (Figure 1A).

\section{Discussion}

We confirmed, by immunoblotting, that several leptospiral proteins were shed in the urine of infected hamsters from the early phase of infection (Figure $2 \mathrm{~B}$ ). On the $7-8^{\text {th }}$ day post-infection, the amount of 52 and $65 \mathrm{kDa}$ leptospiral antigens increased. It was suggested that the proportion of $30 \mathrm{kDa}$ proteins decreased because of rich albumin passing into the urine. Furthermore, we performed 2-DE for a

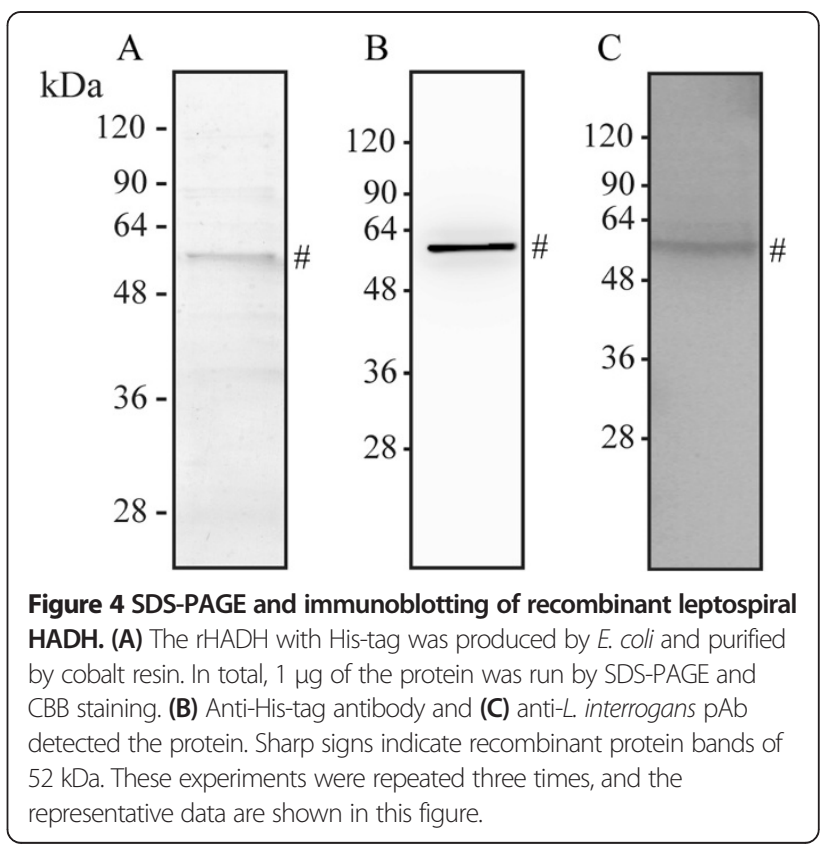

detailed examination of protein components. Patterns of urinary proteins were different between pre-infection and after the seventh day of infection. As mentioned earlier, the infected hamster urine consisted mostly of albumin, consequently we determined proteins that had increased expression. In 2-DE-immunoblotting, $60 \mathrm{kDa}$ proteins were detected by anti-L. interrogans pAb (Figure 3D). However, though proteins with 52 and $30 \mathrm{kDa}$ molecular weights were detected in SDS-PAGE-immunoblotting (Figure 2B), they were not found by 2-DE-immunoblotting (Figure 3D). This may be because the two proteins were diluted in 2-DE gel during pI separation or had specific pI outside 4-7. From the amino acid sequence, molecular weight of $\mathrm{HADH}$ is $52 \mathrm{kDa}$ and this supports the probability that the $52 \mathrm{kDa}$ band in immunoblotting of urine (Figure 2B), recombinant HADH study (Figure 4), and dilution experiments of urine (Figure 5) is leptospiral $\mathrm{HADH}$. However in 2-DE-immunoblotting analysis, anti-

Table 2 List of leptospiral proteins excreted in hamster urine during Leptospira infection

\begin{tabular}{lllllll}
\hline Spot no. & Accession no. $^{+}$ & Locus tag $^{*}$ & Protein annotation & MW (kDa) & pl & Predicted location $^{\#}$ \\
\hline $\mathbf{3 2}$ & gi:45599159 & LIC10012 & Conserved hypothetical protein & 61792 & 9.27 & Unknown \\
& gi:45599713 & LIC10580 & ABC transporter, atp-binding protein & 71297 & 9.3 & Cytoplasmic membrane \\
& gi:45601755 & LIC12676 & conserved hypothetical protein & 76551 & 5.75 & Cytoplasm \\
& gi:45602095 & LIC13023 & conserved hypothetical protein & 51182 & 8.23 & Cytoplasm \\
& gi:45602258 & LIC13191 & conserved hypothetical protein & 65453 & 6.51 & Cytoplasm \\
gi:45602297 & LIC13229 & conserved hypothetical protein & 68742 & 9.21 & Unknown \\
& gi:45602365 & LIC13300 & 3-hydroxyacyl-CoA dehydrogenase & 47865 & 8.65 & Cytoplasm \\
& gi:45602427 & LIC13362 & chloride channel & 67352 & 8.07 & Cytoplasmic membrane \\
\end{tabular}

${ }^{\dagger}$ http://www.ncbi.nlm.nih.gov/protein/.

*http://aeg.lbi.ic.unicamp.br/world/lic/.

\#The proteins were predicted with PSORTb (http://www.psort.org/psortb/). 

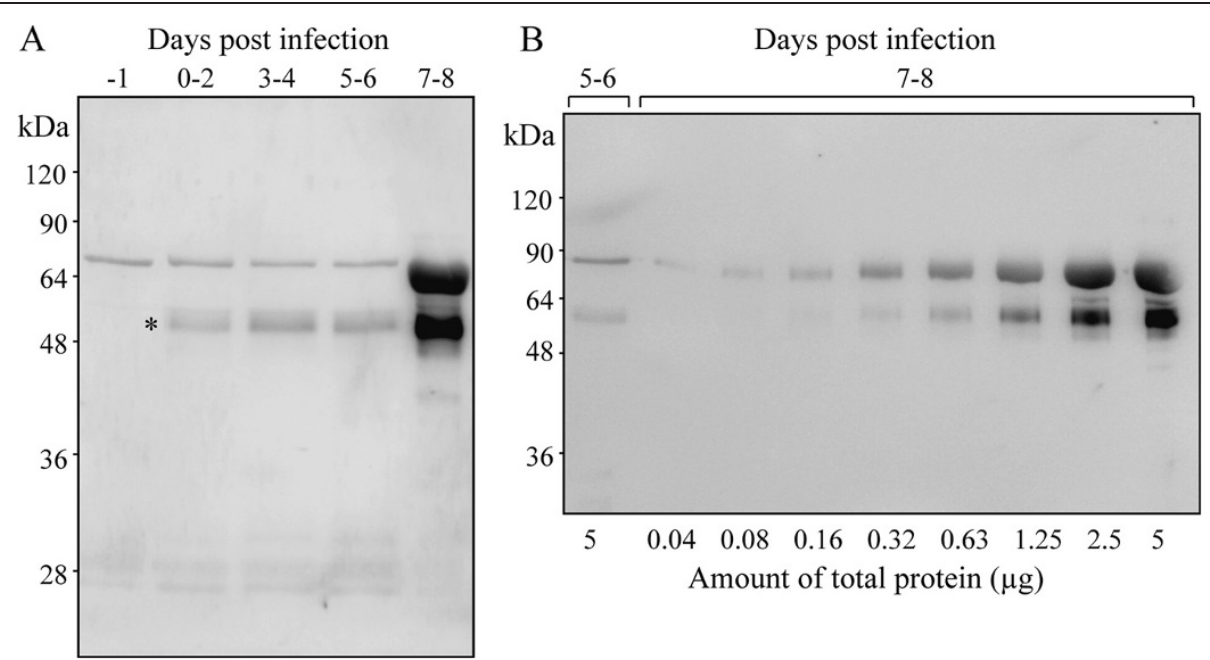

Figure 5 Immunoblotting of infected hamster urine by anti-HADH antisera. (A) Rabbit anti-rHADH serum was able to detect the $52 \mathrm{kDa}$ protein $\left(^{*}\right)$ in the urine of infected hamsters $(n=3)$. Each lane contained $5 \mu \mathrm{g}$ of protein. (B) It was revealed, by serial dilution of urine, that HADH increased in the said specimen during the seventh day post infection. These experiments were repeated three times, and the representative data are shown in this figure.

L. interrogans pAb detected around $60 \mathrm{kDa}$ protein which is revealed as leptospiral HADH by LC/MS/MS. Molecular weight shift like this (from 52 to $60 \mathrm{kDa}$ ) is sometimes observed in these kinds of experiments, and HADH was included in $60 \mathrm{kDa}$ proteins in the 2-DE- immunoblotting (Figure 3D).

The most significant finding in our study was the detection in infected hamster urine of leptospiral protein LIC13300, which is 3-hydroxyacyl-CoA dehydrogenase $(\mathrm{HADH})$ and is one of the intracellular enzyme proteins. This protein is classified as an oxidoreductase in fatty acid metabolic processes. It specifically catalyzes the third step of beta oxidation. Long-chain fatty acids are utilized by Leptospira as the sole carbon source and are metabolized by beta-oxidation. Therefore, a large amount of HADH may be produced intracellularly and released to get carbons and energy by oxidizing free fatty acid.

We produced rabbit antiserum against recombinant leptospiral HADH to detect the protein in infected hamster urine. The advantage of using anti-HADH pAb compared to the anti-pathogenic leptospires $\mathrm{pAb}$ is that the former is more specific than the latter. Using this antiserum, the protein $(52 \mathrm{kDa})$ was successfully detected in urine after infection (Figure 5A), and an increase in band thickness at 7-8 days post infection was confirmed by serial dilution (Figure 5B). It seems that the appearance of $65 \mathrm{kDa}$ protein in immunoblotting (Figure $5 \mathrm{~A}$ ) was due to nonspecific reactions because normal hamster urine had the $65 \mathrm{kDa}$ protein (Figure 5A) and normal rabbit serum also reacted with such protein (data not shown). During 0-6 days after infection, urine still appeared normal and leptospires were not shed in urine. Further study is needed to identify these proteins.
Hamsters and humans also have enzymes similar to leptospiral HADH. The amino acid sequences of this protein are conserved among Leptospira spp., however, the amino acid homology between hamster or human and L. interrogans serovar Copenhageni were only $25.08 \%$ or $32.44 \%$, respectively. It is, therefore, expected that the antisera against leptospiral HADH cannot recognize the protein of hamsters.

Several studies previously reported that the abundant proteins or LPS on the surface of outer membrane were suitable as targets for vaccine and diagnosis of leptospirosis such as outer membrane proteins [38,39], LIC11207 [40], OmpL1 [41,42], MPL17 and MPL21 [43], HbpA [44], LigA [45], LP29 and LP49 [46], LipL32 [47-50], LipL21 [50,51], LipL41 [42], flagellin protein [52]. Moreover, it was also reported that different proteins were expressed in leptospires shed in chronically infected rats compared to leptospires cultured in vitro [53], and that the leptospires in rat urine affected urinary protein composition [54]. However, we were not able to identify any of the previously reported leptospiral proteins in the urine either by immunoblotting with anti- $L$. interrogans $\mathrm{pAb}$ or MS/MS analysis. The polyclonal antibodies were produced in rabbits, and we confirmed that proteins were recognized by this antibody using immunoblotting and MS/MS analyses. The antibody could recognize some membrane proteins such as LipL32 and LipL41 when bacterial cells were used for immunoblotting (unpublished data). However, leptospiral membrane lipoproteins were not detected in the urine, probably due to their low concentration. These results suggest that not only membrane proteins but also intracellular proteins, such as HADH, can be used as candidates for leptospirosis diagnosis. 
We investigated the changes in the attributes of hamster urine prior to infection and a day just before death in a hamster model, and found that the conditions drastically changed one day prior to death. The $\mathrm{pH}$ of hamster urine is usually about 8 , and it was found to have become acidic before death (Figure 1B). Urinary test results suggest that this acidification was caused by renal failure, like nephritis. Hamster urine is usually cloudy due to a high concentration of calcium carbonate [55]. But, it became clear on the day prior to death due to leptospirosis. Calcium carbonate is deposited in alkali conditions, and dissolved in acidic conditions. Leptospira-infected hamster urine was about $\mathrm{pH} 6$, and the urine remained clear even in alkaline condition induced by adding sodium hydroxide. It means that the amount of calcium carbonate excreted in urine decreased just before the hamsters succumbed to infection. After the seventh day of infection, viable leptospires could be recovered from the urine. Thus, it is suggested that leptospires are not shed from the kidneys until just before death.

Most of the urinary proteins detected in this study were associated with host renal failure such as acute renal transplant rejection [29,30], glomerular disease [31,32,36], diabetes mellitus type $2[33,35]$, chronic kidney disease [34], pancreatitis [31], and endemic nephropathy [37]. The proteins identified in our study, except for leptospiral $\mathrm{HADH}$, are biomarkers known to be involved in renal failure, but are not specific for Leptospira infection. Albumin was the main protein detected in infected hamster urine during the end stage of infection (Figure 2). This is one of the plasma proteins and its primary function is to maintain the colloidal osmotic pressure in both the vascular and extra-vascular spaces. The urine-excreted proteins can serve as markers for glomerular disease [31,32] and diabetes [33].

\section{Conclusions}

$\mathrm{HADH}$ was detected in urine before the onset of illness in our hamster model of leptospirosis. This is the first study reporting that leptospiral $\mathrm{HADH}$ is released in the urine during the infection. Therefore, this protein could be applicable in early diagnostic assays for human leptospirosis.

\section{Methods}

\section{Bacteria}

Leptospira interrogans serovar Manilae strain K64 that was isolated from the kidneys of a rat in the Philippines [56] was used in this study, and cultured in modified Korthof's medium supplemented with $10 \%$ rabbit serum at $30^{\circ} \mathrm{C}$. Prior to experiments, strain $\mathrm{K} 64$ was passaged through hamsters to maintain its virulence. Strain K64 passaged less than ten times in vitro was used for experiments. LD50 of strain K64 was determined by infecting hamsters with serially diluted leptospiral suspension $[56,57]$. As a result, the LD50 of K64 strain was $10^{\circ}$.

\section{Animals}

Male golden Syrian hamsters (Japan SLC, Inc., Shizuoka, Japan), 4 weeks of age, were injected subcutaneously with $10^{3}$ low-passaged (less than $10 \times$ in vitro) leptospires at a final volume of $1 \mathrm{ml}$ Korthof's medium. As negative controls, animals were injected with Korthof's medium only. The urine of infected animals was collected by housing them in metabolic chambers for 6 hours daily until they were moribund. Hamster kidneys, livers, spleens, lungs and brains were collected aseptically and squeezed into modified Korthof's medium containing 5-FU using $5 \mathrm{ml}$ syringe, and incubated at $30^{\circ} \mathrm{C}$ [56]. Five hundred microliters of culture supernatant was sub-cultured into fresh medium without 5-FU the next day and was kept at $30^{\circ} \mathrm{C}$ and examined for growth of leptospires daily for one month. Moribund hamsters and those that survived infection after 9 days were sacrificed through inhalation with sevoflurane (Maruishi Pharmaceutical, Japan).

All animal experiments were reviewed and approved by the Ethics Committee on Animal Experiment at the Faculty of Medical Sciences, Kyushu University. The experiments were carried out following the Regulations for Animal Experiments of Kyushu University and The Law (No. 105) and Notification (No. 6) of the Government of Japan.

\section{Urinalysis}

The $\mathrm{pH}$ of hamster urine was tested using $\mathrm{pH}$ test paper BTB (07010060, Advantec, Tokyo, Japan). Glucose, bilirubin, ketone, specific gravity, blood, protein, urobilinogen, nitrite, and leukocyte were measured with N-MULTISTIX ${ }^{\circledR}$ SG-L (Siemens Healthcare Diagnostics Inc., NY). The turbidity of hamster urine was measured using Wallac ARVO sx 1420 multilabel counter (Perkin Elmer, Waltham, MA, USA) at a wavelength of $600 \mathrm{~nm}$.

\section{Pre-treatment of urine for gel electrophoresis}

Due to the small amount of urine collected, urine from three infected hamsters was pooled and used in the experiments. For proteomic analysis, urine samples were first centrifuged at $1500 \times \mathrm{g}$ for $10 \mathrm{~min}$ at $4^{\circ} \mathrm{C}$ to remove debris. The supernatants were concentrated and desalted to remove interfering substances by centrifugation at $7500 \times \mathrm{g}$ for $30 \mathrm{~min}$ at $4^{\circ} \mathrm{C}$ using a centrifugal filter device (Amicon Ultra 4 molecular mass cutoff, 10-kDa; Merck Millipore, Billerica, MA, USA) as previously described [58]. The desalted concentrates were stored at $-20^{\circ} \mathrm{C}$ until further use. Protein concentration in urine was determined using 2-D Quant Kit (GE Healthcare UK Ltd, Little Chalfont, $\mathrm{UK}$ ) and processed for gel electrophoresis.

\section{Sodium dodecyl sulfide-polyacrylamide gel electrophoresis (SDS-PAGE)}

For SDS-PAGE, the concentrated and desalted urine samples were dissolved in Laemmli sample buffer (Bio- 
Rad Laboratories, BioRad, Hercules, CA, USA) with 5\% beta-mercaptoethanol and incubated at $94^{\circ} \mathrm{C}$ for $5 \mathrm{~min}$. SDS-PAGE was performed with $10 \%$ acrylamide gels. Electrophoresis was performed using a Mini-PROTEAN tetra cell (Bio-Rad Laboratories, BioRad, Hercules, CA, USA) for $120 \mathrm{~min}$ at $20 \mathrm{~mA}$ in Tris-glycine running buffer (25 mM Tris, $192 \mathrm{mM}$ glycine, 0.1\% sodium dodecyl sulfate). Separated proteins were stained using Silver Stain MS Kit (WAKO, Osaka, Japan).

\section{Two dimensional electrophoresis (2-DE)}

2-DE of the urine samples was analyzed using the Multiphor II Electrophoresis system (GE Healthcare UK Ltd, Little Chalfont, UK) according to the manufacturer's instructions with some modifications. Briefly, the desalted urine sample was dissolved and recovered with $400 \mu \mathrm{l}$ of $8 \mathrm{M}$ urea, 4\% CHAPS and $50 \mathrm{mM}$ Tris $/ \mathrm{HCl}$ (pH 8.0). Ten mM DTT and 1\% Pharmalyte, broad range $\mathrm{pH}$ 3-10 (GE Healthcare UK Ltd, Little Chalfont, UK) including range $\mathrm{pH}$ 4-7 were added as rehydration buffer prior to loading for the first dimension. Samples were directly added into the rehydration buffer and the $11 \mathrm{~cm}$ immobilized gradient strip ( $\mathrm{pH} 4-7)$ was allowed to swell overnight at room temperature. The isoelectric focusing (IEF) conditions were as follows: (i) $1 \mathrm{~min}$ at a $300 \mathrm{~V}$ gradient, (ii) $1.5 \mathrm{~h}$ at a $3500 \mathrm{~V}$ gradient, (iii) $5 \mathrm{~h}$ at $3500 \mathrm{~V}$, with a $50 \mu \mathrm{A}$ per strip maximum at $15^{\circ} \mathrm{C}$. The completed first-dimensional strip was subjected to 2 -D SDS-PAGE with $12.5 \%$ acrylamide gel. Separated proteins were stained by silver staining as mentioned above.

\section{Cloning and expression of recombinant HADH}

A 1311-bp LIC13300 DNA fragment was amplified using oligomers LIC13300-F 5'-GGAATTCCATATGAGAGA AATCAAAACAGTAACAG-3' and LIC13300-R 5'-CC GCTCGAGTCCTTTGAAAAGTGAACGAGC-3' desig ned based on $L$. interrogans serovar Copenhageni genome sequences (GenBank accession YP_003205). PCR was performed with KOD plus ver. 2 PCR kit (Toyobo, Osaka, Japan) from strain K64. Cycling conditions were: $95^{\circ} \mathrm{C}, 5 \mathrm{~min}$, followed by 40 cycles at $95^{\circ} \mathrm{C}, 1 \mathrm{~min}, 50^{\circ} \mathrm{C}$, $1 \mathrm{~min}, 68^{\circ} \mathrm{C}, 2 \mathrm{~min}$, and a final extension cycle of $5 \mathrm{~min}$, $68^{\circ} \mathrm{C}$. PCR product was digested with NdeI and XhoI (Roche, Basel, Schweiz), ligated to NdeI- and XhoIdigested expression vector, pET-28a $(+)$ (Novagen, San Diego, CA). The ligated plasmid was amplified in E. coli DH5 $\alpha$ and purified using Midi PlusTM Ultrapure Plasmid Extraction System (Viogene, Taipei, Taiwan). After confirming the presence of correct inserts by sequence analysis, the plasmid was transformed in E. coli (DE3). Cultures were grown to $\mathrm{OD}_{600}=0.5$ and protein expression was induced with $1 \mathrm{mM}$ isopropyl-beta-D-thiogalactopyranoside (IPTG), and incubated at $25^{\circ} \mathrm{C}$ overnight. Histagged LIC13300 recombinant protein $(\mathrm{rHADH})$ was purified under native conditions with TALON ${ }^{\circledR}$ Metal Affinity Resin (Clontech) as previously described [59].

\section{Antiserum against rHADH}

One female Japanese white rabbit (Biotek. Co.,Ltd., Japan) weighing $1.5 \mathrm{~kg}$ was immunized subcutaneously with $30 \mu \mathrm{g}$ of the recombinant protein. The $\mathrm{rHADH}$ was mixed with an equal volume of complete Freund's adjuvant (Sigma-Aldrich, St. Louis, MO) to make an emulsion. Four subsequent booster injections were given at twoweek intervals in the same way, by using incomplete Freund's adjuvant (Sigma-Aldrich, St. Louis, MO). One week after the final immunization, the blood of rabbit was collected through cardiac puncture and the serum was analyzed by immunoblotting.

\section{Immunoblotting}

Proteins separated by SDS-PAGE were transferred to an Immobilon-P transfer membrane (Merck Millipore, Billerica, MA, USA) and blocked with 1\% (wt/vol) nonfat dry milk (WAKO, Osaka, Japan) in TBS-0.05\% Tween 20 (TBS-T). The membranes were incubated overnight at $4^{\circ} \mathrm{C}$ with polyclonal antibody produced against live whole cells of L. interrogans serovar Manilae (anti-L. interrogans $\mathrm{pAb}$ ) (1:1000 dilution) [57] or anti-HADH rabbit antiserum polyclonal antibody (1:5000), followed by incubation for $2 \mathrm{~h}$ at room temperature with horseradish peroxidase (HRP)-donkey anti-rabbit IgG conjugate (1:5000 dilution; GE Healthcare UK Ltd, Little Chalfont, UK), or with antiHis (C-term) mouse mAb (1:5000 dilution; Life technologies, Carlsbad, CA, USA), followed by incubation for $2 \mathrm{~h}$ at room temperature with horseradish peroxidase (HRP)sheep anti-mouse IgG conjugate (1:10000 dilution; GE Healthcare UK Ltd, Little Chalfont, UK). The bands were detected with EzWest Lumi plus (ATTO, Tokyo, Japan) and ImageQuant LAS 4000mini (GE Healthcare UK Ltd, Little Chalfont, UK).

\section{Liquid chromatography (LC)/mass spectrometry (MS) analysis}

Protein spots in gels were compared and analyzed by visual inspection. The gel spots were stored in $1 \%$ acetic acid and were subjected to LC/MS/MS analysis. Identification of proteins was carried out using Mascot server (Matrix Science) with datasets of rodent and Leptospira proteomes. A protein score of $>40$ was used to select proteins with significant matching. The difference between the theoretical and experimental mass and pI was also used to determine significant matching.

\section{Additional file}

Additional file 1: Table S1. Amino acid sequence coverage of leptospiral HADH by LC/MS/MS. 


\section{Abbreviations}

HADH: 3-hydroxyacyl-CoA dehydrogenase; CBB: Coomassie brilliant blue; ELISA: Enzyme-linked immunosorbent assay; HRP: Horseradish peroxidase; IEF: Isoelectric focusing; IPTG: Isopropyl-beta-D-thiogalactopyranoside; JICA: Japan International Cooperation Agency; JST: Japan Science and Technology Agency; LC: Liquid chromatography; MS: Mass spectrometry; MAT: Microscopic agglutination test; anti-L. interrogans pAb: Polyclonal antibody produced against live whole cells of L. interrogans serovar Manilae; PCR: Polymerase chain reaction; SATREPS: Science and Technology Research Partnership for Sustainable Development; SDS-PAGE: Sodium dodecyl sulfide-polyacrylamide gel electrophoresis; TBS-T: TBS-0.05\% Tween 20; 2-DE: Two dimensional electrophoresis.

\section{Competing interests}

The authors declare that they have no competing interests.

\section{Authors' contributions}

TS designed portions of the study, carried out all the experiments, and drafted the manuscript. KHN designed portions of the study, participated in the immunoassay, and revised the manuscript. SYAMV participated in the immunoassay and revised the manuscript. MS designed portions of the study and revised the manuscript. KN participated in the proteomic analysis and revised the manuscript. NGG participated in the design of the study. SY conceived and designed portions of the study, and revised the manuscript. All authors read and approved the final manuscript.

\section{Acknowledgments}

This study was supported by a grant of the Science and Technology Research Partnership for Sustainable Development (SATREPS) program from Japan Science and Technology Agency (JST) and Japan International Cooperation Agency (JICA). We thank Dr. H. Sumimoto and colleagues of the Research Support Center, Graduate School of Medical Sciences, Kyushu University for their technical support and advice. We also thank Sayaka Akiyoshi, Takayoshi Yamaguchi, Hideko Kameyama, and Naomi Hidaka for their technical cooperation.

\section{Author details}

${ }^{1}$ Department of Bacteriology, Graduate School of Medical Sciences, Kyushu University, Fukuoka 812-8582, Japan. ²Department of Biological Sciences, Graduate School of Sciences, Kyushu University, Fukuoka 812-8582, Japan. ${ }^{3}$ Department of Medical Microbiology, College of Public Health, University of the Philippines-Manila, Manila 1000, Philippines.

Received: 26 December 2013 Accepted: 7 May 2014

Published: 21 May 2014

\section{References}

1. Levett PN: Leptospirosis. Clin Microbiol Rev 2001, 14(2):296-326.

2. Bharti AR, Nally JE, Ricaldi JN, Matthias MA, Diaz MM, Lovett MA, Levett PN, Gilman RH, Willig MR, Gotuzzo E, Vinetz JM, Peru-United States Leptospirosis Consortium: Leptospirosis: a zoonotic disease of global importance. Lancet Infect Dis 2003, 3(12):757-771.

3. Picardeau M: Diagnosis and epidemiology of leptospirosis. Med Mal Infect 2013, 43(1):1-9.

4. Adler B, de la Pena MA: Leptospira and leptospirosis. Vet Microbio/ 2010 140(3-4):287-296.

5. Toyokawa T, Ohnishi M, Koizumi N: Diagnosis of acute leptospirosis. Expert Rev Anti Infect Ther 2011, 9(1):111-121.

6. Vijayachari P, Sugunan AP, Shriram AN: Leptospirosis: an emerging global public health problem. J Biosci 2008, 33(4):557-569.

7. Camargo ED, da Silva MV, Batista L, Vaz AJ, Sakata EE: An evaluation of the ELISA-IgM test in the early diagnosis of human leptospirosis. Rev Inst Med Trop Sao Paulo 1992, 34(4):355-357.

8. Fonseca Cde A, Teixeira MM, Romero EC, Tengan FM, Silva MV, Shikanai-Yasuda MA: Leptospira DNA detection for the diagnosis of human leptospirosis. $J$ Infect 2006, 52(1):15-22.

9. Balassiano IT, Vital-Brazil JM, Pereira MM: Leptospirosis diagnosis by immunocapture polymerase chain reaction: a new tool for early diagnosis and epidemiologic surveillance. Diagn Microbiol Infect Dis 2012, 74(1):11-15.
10. Koizumi N, Watanabe H, Umezawa K, liduka T, Inokuchi S: A case of leptospirosis diagnosed early by flaB-PCR. Kansenshogaku Zasshi 2003, 77(8):627-630

11. Brown PD, Gravekamp C, Carrington DG, van de Kemp H, Hartskeerl RA, Edwards CN, Everard CO, Terpstra WJ, Levett PN: Evaluation of the polymerase chain reaction for early diagnosis of leptospirosis. J Med Microbiol 1995, 43(2):110-114.

12. Goris MG, Leeflang MM, Loden M, Wagenaar JF, Klatser PR, Hartskeerl RA Boer KR: Prospective evaluation of three rapid diagnostic tests for diagnosis of human leptospirosis. PLoS Negl Trop Dis 2013, 7(7):e2290.

13. Ooteman MC, Vago AR, Koury MC: Evaluation of MAT, IgM ELISA and PCR methods for the diagnosis of human leptospirosis. J Microbiol Methods 2006, 65(2):247-257.

14. McBride AJ, Santos BL, Queiroz A, Santos AC, Hartskeerl RA, Reis MG, Ko Al: Evaluation of four whole-cell Leptospira-based serological tests for diagnosis of urban leptospirosis. Clin Vaccine Immunol 2007, 14(9):1245-1248.

15. Bajani MD, Ashford DA, Bragg SL, Woods CW, Aye T, Spiegel RA, Plikaytis BD, Perkins BA, Phelan M, Levett PN, Weyant RS: Evaluation of four commercially available rapid serologic tests for diagnosis of leptospirosis. J Clin Microbiol 2003, 41(2):803-809.

16. Eapen CK, Sugathan S, Kuriakose M, Abdoel T, Smits HL: Evaluation of the clinical utility of a rapid blood test for human leptospirosis. Diagn Microbiol Infect Dis 2002, 42(4):221-225.

17. Signorini ML, Lottersberger J, Tarabla HD, Vanasco NB: Enzyme-linked immunosorbent assay to diagnose human leptospirosis: a meta-analysis of the published literature. Epidemiol Infect 2013, 141(1):22-32.

18. Musso D, La Scola B: Laboratory diagnosis of leptospirosis: a challenge. J Microbiol Immunol Infect 2013, 46(4):245-252.

19. Widiyanti D, Koizumi N, Fukui T, Muslich LT, Segawa T, Villanueva SY, Saito M, Masuzawa T, Gloriani NG, Yoshida S: Development of immunochromatography-based methods for detection of leptospiral lipopolysaccharide antigen in urine. Clin Vaccine Immunol 2013, 20(5):683-690

20. Saengjaruk P, Chaicumpa W, Watt G, Bunyaraksyotin G, Wuthiekanun V, Tapchaisri P, Sittinont C, Panaphut T, Tomanakan K, Sakolvaree Y, ChongsaNguan M, Mahakunkijcharoen Y, Kalambaheti T, Naigowit P, Wambangco MA, Kurazono $H_{1}$ Hayashi $\mathrm{H}$ : Diagnosis of human leptospirosis by monoclonal antibody-based antigen detection in urine. J Clin Microbiol 2002, 40(2):480-489.

21. Ruiz VM, Vega LE, Velazquez RM: Use of polymerase chain reaction for the identification of Leptospira sp. in urine of carriers. Rev Cubana Med Trop 2005, 57(1):47-48.

22. Koizumi N, Nakajima C, Harunari T, Tanikawa T, Tokiwa T, Uchimura E, Furuya T, Mingala CN, Villanueva MA, Ohnishi M, Suzuki Y: A new loopmediated isothermal amplification method for rapid, simple, and sensitive detection of Leptospira spp. in urine. J Clin Microbiol 2012, 50(6):2072-2074

23. Bomfim MR, Barbosa-Stancioli EF, Koury MC: Detection of pathogenic leptospires in urine from naturally infected cattle by nested PCR. Vet $J$ 2008, 178(2):251-256.

24. Suwimonteerabutr J, Chaicumpa W, Saengjaruk P, Tapchaisri P, Chongsanguan M, Kalambaheti T, Ramasoota P, Sakolvaree Y, Virakul P: Evaluation of a monoclonal antibody-based dot-blot ELISA for detection of Leptospira spp in bovine urine samples. Am J Vet Res 2005, 66(5):762-766.

25. Bal AE, Gravekamp C, Hartskeerl RA, De Meza-Brewster J, Korver H, Terpstra WJ: Detection of leptospires in urine by PCR for early diagnosis of leptospirosis. J Clin Microbiol 1994, 32(8):1894-1898.

26. Bolin CA, Zuerner RL, Trueba G: Comparison of three techniques to detect Leptospira interrogans serovar Hardjo type hardjo-bovis in bovine urine. Am J Vet Res 1989, 50(7):1001-1003.

27. Rai AJ: The urinary proteome. 2010, 641:361. https://library.plantandfood. co.nz/cgi-bin/koha/opac-detail.pl?biblionumber=18633.

28. Haake DA: Hamster model of leptospirosis. Curr Protoc Microbiol 2006, Chapter 12(Unit 12E):2.

29. Sigdel TK, Kaushal A, Gritsenko M, Norbeck AD, Qian WJ, Xiao W, Camp DG 2nd, Smith RD, Sarwal MM: Shotgun proteomics identifies proteins specific for acute renal transplant rejection. Proteomics Clin Appl 2010, 4(1):32-47.

30. Loftheim H, Midtvedt K, Hartmann A, Reisaeter AV, Falck P, Holdaas H, Jenssen $T$, Reubsaet $L$, Asberg A: Urinary proteomic shotgun approach for 
identification of potential acute rejection biomarkers in renal transplant recipients. Transplant Res 2012, 1(1):9. http://www.transplantationresearch. com/content/1/1/9.

31. Burtis CA, Ashwood ER, Tietz NW: Tietz Textbook of Clinical Chemistry. 3rd edition. Philadelphia: W.B. Saunders; 1999.

32. Varghese SA, Powell TB, Budisavljevic MN, Oates JC, Raymond JR, Almeida JS, Arthur JM: Urine biomarkers predict the cause of glomerular disease. J Am Soc Nephrol 2007, 18(3):913-922.

33. Riaz S, Skinner V, Srai SK: Effect of high dose thiamine on the levels of urinary protein biomarkers in diabetes mellitus type $2 . J$ Pharm Biomed Anal 2011, 54(4):817-825.

34. Burns $\mathrm{KD}$, Hiremath $\mathrm{S}$ : Urinary angiotensinogen as a biomarker of chronic kidney disease: ready for prime time? Nephrol Dial Transplant 2012, 27(8):3010-3013.

35. Penders J, Delanghe JR: Alpha 1-microglobulin: clinical laboratory aspects and applications. Clin Chim Acta 2004, 346(2):107-118.

36. Short $C D$, Durrington $P N$, Mallick NP, Hunt $L P$, Tetlow $L$, Ishola M: Serum and urinary high density lipoproteins in glomerular disease with proteinuria. Kidney Int 1986, 29(6):1224-1228.

37. Pesic I, Stefanovic V, Muller GA, Muller CA, Cukuranovic R, Jahn O, Bojanic V, Koziolek M, Dihazi H: Identification and validation of six proteins as marker for endemic nephropathy. J Proteomics 2011, 74(10):1994-2007.

38. Lessa-Aquino C, Borges Rodrigues C, Pablo J, Sasaki R, Jasinskas A, Liang L, Wunder EA Jr, Ribeiro GS, Vigil A, Galler R, Molina D, Liang X, Reis MG, Ko Al, Medeiros MA, Felgner PL: Identification of seroreactive proteins of Leptospira interrogans serovar Copenhageni using a high-density protein microarray approach. PLoS Negl Trop Dis 2013, 7(10):e2499.

39. Raja V, Natarajaseenivasan K: Pathogenic, diagnostic and vaccine potential of leptospiral outer membrane proteins (OMPs). Crit Rev Microbiol 2013, http://informahealthcare.com/doi/abs/10.3109/1040841X.2013.787387.

40. Pretre G, Lapponi MJ, Atzingen MV, Schattner M, Nascimento AL, Gomez RM: Characterization of LIC11207, a novel leptospiral protein that is recognized by human convalescent sera and prevents apoptosis of polymorphonuclear leukocytes. Microb Pathog 2013, 56:21-28.

41. Subathra M, Senthilkumar TM, Ramadass P: Recombinant OmpL1 protein as a diagnostic antigen for the detection of canine leptospirosis. Appl Biochem Biotechnol 2013, 169(2):431-437.

42. Natarajaseenivasan K, Vijayachari P, Sharma S, Sugunan AP, Selvin J, Sehgal SC: Serodiagnosis of severe leptospirosis: evaluation of ELISA based on the recombinant OmpL1 or LipL41 antigens of Leptospira interrogans serovar Autumnalis. Ann Trop Med Parasitol 2008, 102(8):699-708.

43. Oliveira TR, Longhi MT, de Morais ZM, Romero EC, Blanco RM, Kirchgatter K, Vasconcellos SA, Nascimento AL: Evaluation of leptospiral recombinant antigens MPL17 and MPL21 for serological diagnosis of leptospirosis by enzyme-linked immunosorbent assays. Clin Vaccine Immunol 2008, 15(11):1715-1722.

44. Sridhar V, Manjulata Devi S, Ahmed N, Sritharan M: Diagnostic potential of an iron-regulated hemin-binding protein $\mathrm{HbpA}$ that is widely conserved in Leptospira interrogans. Infect Genet Evol 2008, 8(6):772-776

45. Srimanote $P$, Wongdeethai $N$, Jieanampunkul $P$, Samonkiert $S$, Leepiyasakulchai C, Kalambaheti T, Prachayasittikul V: Recombinant LigA for leptospirosis diagnosis and LigA among the Leptospira spp. clinical isolates. J Microbiol Methods 2008, 72(1):73-81.

46. Neves FO, Abreu PA, Vasconcellos SA, de Morais ZM, Romero EC, Nascimento AL: Identification of a novel potential antigen for early-phase serodiagnosis of leptospirosis. Arch Microbiol 2007, 188(5):523-532.

47. Coutinho ML, Vasconcellos FA, Fernandes CP, Seyffert N, Seixas FK, Ko Al, Dellagostin OA, Aleixo JA: Evaluation of the anti-LipL32 monoclonal antibodies potential for use in leptospirosis immunodiagnostic tests. J Immunoassay Immunochem 2007, 28(3):279-288.

48. Humphryes PC, Weeks ME, Gielbert A, Thomson G, Coldham NG: Analysis of multiple Leptospira interrogans serovar Canicola vaccine proteomes and identification of LipL32 as a biomarker for potency. Clin Vaccine Immunol 2012, 19(4):587-593.

49. Kucerova P, Cermakova Z, Pliskova L, Pavlis O, Kubickova P, Kleprlikova H, Valenta Z: Our experience using real-time PCR for the detection of the gene that encodes the superficial lipoprotein LipL32 of the pathogenic leptospires to confirm the acute form of human leptospirosis. Biomed Pap Med Fac Univ Palacky Olomouc Czech Repub 2013, 157(4):387-391.

50. Cheemaa PS, Srivastava SK, Amutha R, Singh S, Singh H, Sandey M: Detection of pathogenic leptospires in animals by PCR based on lipL21 and lipL32 genes. Indian J Exp Biol 2007, 45(6):568-573.
51. Joseph S, Thomas N, Thangapandian E, Singh VP, Verma R, Srivastava SK: Evaluation and comparison of native and recombinant LipL21 proteinbased ELISAs for diagnosis of bovine leptospirosis. J Vet Sci 2012, 13(1):99-101.

52. Bughio NI, Lin M, Surujballi OP: Use of recombinant flagellin protein as a tracer antigen in a fluorescence polarization assay for diagnosis of leptospirosis. Clin Diagn Lab Immunol 1999, 6(4):599-605.

53. Monahan AM, Callanan JJ, Nally JE: Proteomic analysis of Leptospira interrogans shed in urine of chronically infected hosts. Infect Immun 2008, 76(11):4952-4958.

54. Nally JE, Monahan AM, Miller IS, Bonilla-Santiago R, Souda P, Whitelegge JP: Comparative proteomic analysis of differentially expressed proteins in the urine of reservoir hosts of leptospirosis. PLoS One 2011, 6(10):e26046.

55. Syrian Hamsters: biology: urine. http://ehs.uc.edu/lams/data/hamsters/ 9028/28_031.html.

56. Villanueva SY, Ezoe H, Baterna RA, Yanagihara Y, Muto M, Koizumi N, Fukui T, Okamoto Y, Masuzawa T, Cavinta LL, Gloriani NG, Yoshida S: Serologic and molecular studies of Leptospira and leptospirosis among rats in the Philippines. Am J Trop Med Hyg 2010, 82(5):889-898.

57. Villanueva SY, Saito M, Tsutsumi Y, Segawa T, Baterna RA, Chakraborty A, Asoh T, Miyahara S, Yanagihara Y, Cavinta LL, Gloriani NG, Yoshida SI: High virulence in hamsters of four dominantly prevailing Leptospira serovars isolated from rats in the Philippines. Microbiology 2014, 160(Pt 2):418-428.

58. Yokota H, Hiramoto M, Okada H, Kanno Y, Yuri M, Morita S, Naitou M, Ichikawa A, Katoh M, Suzuki H: Absence of increased alpha1-microglobulin in IgA nephropathy proteinuria. Mol Cell Proteomics 2007, 6(4):738-744.

59. Yoshimura S, Haas AK, Barr FA: Analysis of Rab GTPase and GTPaseactivating protein function at primary cilia. Methods Enzymol 2008, 439:353-364.

doi:10.1186/1471-2180-14-132

Cite this article as: Segawa et al.: Identification of leptospiral 3-hydroxyacylCoA dehydrogenase released in the urine of infected hamsters. BMC Microbiology 2014 14:132.

\section{Submit your next manuscript to BioMed Central and take full advantage of:}

- Convenient online submission

- Thorough peer review

- No space constraints or color figure charges

- Immediate publication on acceptance

- Inclusion in PubMed, CAS, Scopus and Google Scholar

- Research which is freely available for redistribution

Submit your manuscript at www.biomedcentral.com/submit
C) Biomed Central 